\title{
SEKSUALINIUS NUSIKALTIMUS İVYKDŽIUSIŲ ASMENŲ, KURIEMS KONSTATUOTI PSICHIKOS IR ELGESIO SUTRIKIMAI VARTOJANT PSICHOAKTYVIĄSIAS MEDŽIAGAS, TEISMO PSICHIATRINIS VERTINIMAS
}

\author{
Aurelija Survilaitè \\ Valstybine teismo psichiatrijos tarnyba prie Sveikatos apsaugos ministerijos
}

Raktažodžiai: seksualiniai nusikaltimai, psichikos ir elgesio sutrikimai vartojant psichoaktyviąsias medžiagas, teismo psichiatrijos ekspertizès baudžiamosiose bylose.

\begin{abstract}
Santrauka
Tyrimo metu buvo atrinkti teismo psichiatrijos ekspertizių aktai, atlikti Valstybineje teismo psichiatrijos tarnyboje prie SAM 2010 - 2016 m. laikotarpiu, kuriuose asmenys buvo įtariami/kaltinami įvykdę seksualinio pobūdžio nusikaltimus ir kuriems buvo diagnozuoti bet kokie psichikos ir elgesio sutrikimai vartojant psichoaktyviąsias medžiagas. Atlikta minètų asmenų psichinès būsenos bei socialinių - demografinių charakteristikų, nusikalstamos veikos, teismo psichiatrinio vertinimo analizè. Gauti rezultatai parode, kad alkoholis buvo dažniausiai vartojama psichoaktyvi medžiaga ir daugiau nei $80 \%$ seksualinius nusikaltimus įvykdžiusių asmenų buvo apsvaigę nuo alkoholio. Psichikos būsenos vertinime dominavo emocinis labilumas, impulsyvumas bei žemi intelektiniai gebejjimai. Dažnas psichikos ir elgesio sutrikimų vartojant psichoaktyviąsias medžiagas komorbidiškumas su asmenybès spektro sutrikimais bei protiniu atsilikimu. Tik 3 seksualinius nusikaltimus ivykdžiusiems asmenims buvo konstatuoti sunkūs psichikos sutrikimai, dèl kurių jie negalèjo suvokti veikos pavojingumo ir valdyti savo veiksmų. Minètiems asmenims rekomenduota taikyti priverčiamąsias medicinos priemones.
\end{abstract}

\section{İvadas}

Didele dalis nusikaltimų asmens seksualinio apsisprendimo laisvei ir neliečiamumui yra padaromi asmenų, apsvaigusių nuo psichoaktyvių medžiagų, o ypač alkoholio. Psichoaktyvių medžiagų vaidmuo smurtinių nusikaltimų, tarp jų ir seksualinių nusikaltimų, srityje - tyrejus dominanti ir pastaruoju metu itin aktualizuojama tema. Diskutuojama, kokią ịtaką psichoaktyvių medžiagų vartojimas daro smurtinio nusikaltimo rizikos padidejimui, taip pat kiek tam tikri asmenybės struktūros ir individualūs charakterio ypatumai, pasireiškiantys abejingumu konvencinėms elgesio normoms, yra reikšmingi žalingam psichoaktyvių medžiagų vartojimui ir priklausomybės susiformavimui. Skirtingų asmenų seksualinio nusikaltimo motyvuojantys faktoriai gali būti labai ịvairūs, kaip ir skirtingi aplinkos veiksniai, todèl negalima vienareikšmiškai teigti, jog tarp seksualinio nusikaltimo ir psichoaktyvių medžiagų vartojimo yra tiesioginis priežastinis ryšys, tačiau, ịvairių studijų duomenimis, tiek ilgalaikis, tiek trumpalaikis psichoaktyvių medžiagų vartojimas vis dèlto padidina kriminalinio elgesio riziką [1]. Aspektai taip pat ịvairūs - apsvaigus nuo psichoaktyvių medžiagų iš esmès keičiasi aplinkos suvokimas bei ịvertinimas, susilpnèja savikontrolè, keičiasi emocinių išgyvenimų ir poelgių pobūdis, dažnai pervertinamos savo galimybès, t. y. ankstyvuose agresoriaus ir aukos sąveikos etapuose pervertinama tikimybè, jog auka domisi agresoriumi seksualiai bei nori lytiškai santykiauti. Kadangi socialinè sąveika yra ne momentinis, o tęstinis veiksmas, eigoje agresorius vis pakartotinai vertina tiek verbalinius, tiek neverbalinius aukos signalus, o apsvaigimas nuo psichoaktyvių medžiagų sumažina tikimybę, kad minèti signalai bus apdoroti tinkamai ir bus atsisakyta pirminių troškimų. Antra vertus, asmenybès struktūroje dominuojant tam tikriems asmenybės bruožams ir charakterio ypatumams, apsvaigimas nuo psichoaktyvių medžiagų gali padidinti tikimybę pasielgti agresyviai, kadangi neagresyvūs seksualinio pasitenkinimo sprendimai sunkiai randami, dèmesys sutelkiamas troškimo patenkinimui, negalvojant apie tolesnes tokio elgesio teisines ir moralines pasekmes. Agresyvaus elgesio rizika gali didèti, jei auka taip pat apsvaigusi nuo psichoaktyvių medžiagų, nes tai apriboja jos galimybes veiksmingai pasipriešinti [2-4].

Teismo psichiatrijos ekspertizès seksualinius nusikalti- 
mus ịvykdžiusiems asmenims skiriamos siekiant ịvertinti, ar minètas asmuo turi kokị nors psichikos sutrikimą ir ar šis psichikos sutrikimas turejo įtakos asmens gebejjimui suprasti savo veiksmų esmę ir juos valdyti nusikaltimo padarymo metu. Priklausomybè nuo psichoaktyvių medžiagų ar žalingas jų vartojimas nėra laikoma pagrindu pripažinti asmenị nepakaltinamu ar ribotai pakaltinamu, tačiau teismo psichiatrų ar teismo psichologų praktikoje nustatomas itin dažnas psichikos sutrikimų dėl psichoaktyvių medžiagų vartojimo komorbidiškumas su kitais psichikos sutrikimais.

Šiame tyrime bandyta panagrinèti priklausomų nuo psichoaktyvių medžiagų ar žalingai jas vartojančių asmenų, ịvykdžiusių seksualinį nusikaltimą, psichikos ypatumus bei nusikalstamo elgesio priežastis. Žinoma, tyrimo duomenys leidžia tik kelti prielaidas apie tiriamų asmenų seksualinès prievartos motyvus ir asmenybės ypatumus, kadangi tyrimą apriboja tam tikri faktoriai kaip tiriamujų nenoras atvirauti arba sąmoningai pateiktas iškraipytas ịvykių atpasakojimas. Taip pat praejjęs laikotarpis po nusikaltimo gali tureti ịtakos tiriamojo atsiminimams - jie gali būti netikslūs, ypač jei veikos metu asmuo buvo apsvaigęs nuo psichoaktyvių medžiagu. Taip pat nepavyko tarpusavyje palyginti asmenybės ir nusikalstamos veikos ypatumų asmenų, vartojusių skirtingas psichoaktyviąsias medžiagas dèl didelio šių grupių imties netolygumo.

Darbo tikslas: įvertinti asmenų, ịvykdžiusių seksualinị nusikaltimą, kuriems diagnozuoti psichikos ir elgesio sutrikimai vartojant psichoaktyviąsias medžiagas ir kuriems buvo atlikta teismo psichiatrijos ekspertizès, psichinès būsenos, asmenybès struktūros bei sociodemografinius ypatumus, jų ịtaką nusikalstamai veikai, nusikalstamos veikos motyvus.

\section{Tyrimo medžiaga ir metodika}

Atlikta retrospektyvinė 2010 m. - 2016 m. laikotarpiu baudžiamajame procese atliktų teismo psichiatrijos - teismo psichologijos ekspertizių aktų, atrinktų pagal autoriaus sudarytą klausimyną, analizè. Tiriamają grupę sudare 51 tiriamasis, kuris buvo įtariamas arba kaltinamas padaręs seksualini nusikaltimą ir kuriam iki nusikalstamos veikos padarymo buvo diagnozuoti psichikos ir elgesio sutrikimai vartojant bet kokią psichoaktyviają medžiagą.

\section{Rezultatai}

Analizuojant medžiagą nustatyta, kad 2010 - 2016 m. laikotarpiu Valstybinejje teismo psichiatrijos tarnyboje buvo atliktos 1784 teismo psichiatrijos - teismo psichologijos ekspertizès baudžiamosiose bylose pilnamečiams asmenims, kuriems konstatuoti psichikos ir elgesio sutrikimai vartojant psichoaktyviąsias medžiagas, iš jų 254 asmenims buvo konstatuoti psichikos ir elgesio sutrikimai vartojant narkotines ir psichotropines medžiagas, o 1530 asmenims - psichikos ir elgesio sutrikimai vartojant alkoholị. Asmenų, kuriems konstatuoti bet kokie psichikos ir elgesio sutrikimai vartojant psichoaktyviąsias medžiagas, per tiriamą laikotarpị seksualiniai nusikaltimai sudare 2,8 proc. tarp kitų nusikaltimų (N-51). Asmenims, kuriems diagnozuoti psichikos ir elgesio sutrikimai vartojant psichoaktyviąsias medžiagas ir kurie padarè seksualinị nusikaltimą, teismo psichiatrijos - teismo psichologijos ekspertizių per metus atliekama nedaug - didžiausias skaičius tokių ekspertizių buvo atliktas $2011 \mathrm{~m}$. - jų buvo 15. Vèlesniu laikotarpiu stebima palaipsniui mažèjanti tendencija - $2016 \mathrm{~m}$. buvo atliktos tik 2 ekspertizès tokiems asmenims. Išanalizavus medžiagą nustatyta, kad 84,3 proc. tiriamosios grupès sudare asmenys, kuriems diagnozuoti psichikos ir elgesio sutrikimai vartojant alkoholį, 5,9 proc. sudare mišrus alkoholio ir narkotinių medžiagų vartojimas, 9,8 proc. - kitų psichoaktyvių medžiagų, išskyrus alkoholį, vartojimas.

Išanalizavus sociodemografines tiriamujų charakteristikas nustatyta, kad 49 proc. tiriamujų buvo jauno, iki 35 metų, amžiaus. Vyriausias tiriamasis - 75 metų amžiaus. Didžioji dalis tiriamujų (59 proc.) iki nusikalstamos veikos padarymo buvo nedirbantys, neturintys pakankamų pajamų, pažymèta finansinè priklausomybė nuo artimujų. 41 proc. tiriamujų turejjo nuolatinị oficialų darbą arba mokèsi. Net 25,5 proc. tiriamujų nebuvo igiję vidurinio išsilavinimo, o 5,9 proc. iš jų buvo apskritai neraštingi. 13,7 proc. tiriamujų buvo baigę specialaus ugdymo programą, adaptuotą intelekto gebejjimų deficitą turintiems asmenims. Daugiausia tiriamųjų buvo igiję vidurinị arba profesinị išsilavinimą (54,9 proc.). Asmenys su aukštuoju išsilavinimu sudare tik 5,9 proc. 51 proc. tiriamujų buvo vieniši, nesukūrę šeimos, 13,7 proc. išsiskyrę, gyveno vieni. 35,3 proc. tiriamuju gyveno su partneriu, iš jų 13,7 proc. - santuokoje. Tiriamujų grupeje, kurie nurodè gyvenantys su partneriu, fiksuoti dažni partnerių tarpusavio konfliktai, daugkartiniai išsiskyrimai ir susitaikymai. Neretai sutuoktinè ar sugyventine taip pat piktnaudžiavo psichoaktyviomis medžiagomis, ypač alkoholiu. Iš visos tiriamosios grupès asmenų tik 33,3 proc. turejjo vaikų, vidutiniškai po 2 - 3. Visi šios grupés tiriamieji nurode, kad savo vaikų tiek finansiniu išlaikymu, tiek auklejjimu menkai rūpinosi, atsakomybę už vaikų priežiūrą perleisdami vaikų motinoms. Apie 66,7 proc. tiriamujų vaikų niekada nebuvo susilaukę. Didžioji dalis tiriamujų $(47,1$ proc.) patys buvo kilę iš šeimos, kurioje augo 2-3 vaikai, 29,4 proc. - kurioje augo 4-5 vaikai, 11,8 proc. - kurioje augo 6-9 vaikai. 5,9 proc. augo vienturčiai. 5,9 proc. tiriamujų augo šeimoje, kurioje buvo daugiau nei 10 vaikų (didžiausias vaikų skaičius šeimoje buvo 16). Nustatyta, kad 41,2 proc. tiriamujų augo su vienu iš tèvų, 7,8 proc. - augo vaikų namuose, o 
net 51 proc. tiriamujų turejo galimybę augti kartu su abiem tèvais. Iš visų tirtujų asmenų net 80,4 proc. augo prastomis psichosocialinèmis sąlygomis, t. y. šių asmenų pedagoginiam išsilavinimui nebuvo skiriamas demesys arba jis buvo nepakankamas, tiriamujų tèvai ar vienas iš tèvų ar globejų buvo patys piktnaudžiaujantys alkoholiu, šeimoje finansine padètis buvo prasta, šios šeimos buvo stebimos socialinių darbuotojų dèl socialinių arba tėvystès ịgūdžiu stokos. 19,6 proc. tiriamujų gyvenimo sąlygos vaikystejje buvo apibūdintos kaip tinkamos. Tiriamosios grupès asmenys pasižymejjo ankstyva alkoholizacija - beveik 68,6 proc. asmenų alkoholi pradèjo vartoti nesulaukę pilnametystès, būdami vidutiniškai 12-13 metų amžiaus. Ankstyvas narkotinių medžiagų vartojimas buvo užfiksuotas tik 3 atvejais. 31,4 proc. tiriamujų nurodè, kad alkoholị vartoti pradejjo jau būdami pilnamečiai, o būtent, karinès tarnybos metu (,nes visi ten gère“") arba iš karto po jos (,neturejjau darbo, nebuvo ką veikti“, ,pradejjau dirbti, visi ten gèré"). Tik 2 asmenims alkoholio vartojimas pasireiškè kaip antrinis veiksnys - sunkaus psichikos sutrikimo pasekmé.

Nagrinejjant kriminalinio elgesio aplinkybes, nustatyta, $\operatorname{kad} 33,3$ proc. tiriamujų buvo teisiami pirmą kartą, 25,5 proc. - anksčiau jau buvę teisti už seksualinio pobūdžio nusikaltimus, 11,8 proc. buvę teisti už smurtinio pobūdžio nusikaltimus ir 11,8 proc. už kitus nusikaltimus (pvz., vagystes, plěšimus, viešosios tvarkos pažeidimus ir kt.). 51 proc. tiriamujjų nagrinejjamą seksualinę prievartą atliko savo gyvenamojoje vietoje, 19,6 proc. atvejų seksualinis nusikaltimas įvykdytas tiriamojo draugų/pažįstamų gyvenamojoje vietoje, kur tuo metu buvo girtaujama. Ir net 23,5 proc. seksualiniu nusikaltimų ỉvykdyta kitose nuošaliose vietose, tokiose kaip apleistas pastatas, liftas, pagalbinès paskirties statinys ir pan. 5,9 proc. aukų nukentejjo savo pačių gyvenamoje vietoje. Net 74,5 proc. seksualinès prievartos atvejų buvo invazyvūs, t. y. auka buvo seksualiai prievartauta oraliniu, analiniu ar vaginaliniu būdu. 25,5 proc. atvejų atlikti tvirkinamieji veiksmai, verčiant auką liesti nusikaltėlio lytinius organus, liečiant aukos lytinius organus ar verčiant stebèti masturbacijos aktą. Iš visų tiriamujų net 80,4 proc. kaltės dèl nusikalstamos veikos padarymo visiškai nepripažino, stengèsi save pateisinti, atsakomybę už savo veiksmus perkeliant nukentejusiajam, jo artimiesiems (,priverte parašyti pareiškimą“) ar nepalankiai susiklosčiusioms išorinėms aplinkybėms, buvo gana gynybiški, nelinkę atskleisti nusikalstamos veikos detalių. Nusikalstamos veikos motyvacija didele dalimi liko neaiški, 49 proc. tiriamujjų kategoriškai neige įvykdę nusikalstamą veiką, jokių aplinkybių nepaaiškino, nurode, kad ,tokio ivykio apskritai nebuvo“", kaltino auką davus melagingus parodymus ar „viską išsigalvojus“, galimai siekiant antrinès naudos, pvz., „gauti pinigų“, „išvaryti iš namų“, „uždaryti i kalèjimą“, „iš keršto apkaltino“ ir pan. 9,8 proc. tiriamujų nurodè nusikalstamos veikos aplinkybių nepamenantys dèl buvusio sunkaus apsvaigimo nuo alkoholio. 21,6 proc. tiriamujų pripažino buvus patị seksualini aktą, tačiau kategoriškai neigè seksualinę prievartą, savo elgesị motyvuodami tuo, kad seksualinis aktas vyko abipusiu sutarimu, auka ,pati norèjo“. 19,6 proc. tiriamujjų kaltę dèl nusikalstamos veikos padarymo pripažino, iš jų 15,7 proc. nurodè tiesiogiai siekę patenkinti savo seksualinị potraukị (,užsinorèjau sekso“, ,negalejjau susilaikyti, tiesiog norejjau sekso"). 3,9 proc. asmenų kaltę pripažino, tačiau nurodè nežinoję darantys nusikaltimą, t. y. teigè nežinoję, kad seksualinių poreikių tenkinimą su pilnametystès nesulaukusiais asmenimis draudžia Lietuvos Respublikos įstatymai. Net 80 proc. tiriamujų veiką atliko būdami apsvaigę nuo alkoholio, 3,9 proc. konstatuotas mišrus apsvaigimas nuo alkoholio ir kelių narkotinių medžiagų. Atliekant seksualinį nusikaltimą, fizinis smurtas buvo panaudotas 47,1 proc. atvejų, iš jų net 1 auka buvo nužudyta siekiant nuslèpti nusikaltimo motyvus ir 1 auką pasikèsinta nužudyti. 52,9 proc. atvejų aukos buvo įtikinëjamos grasinant panaudoti fizini smurtą arba pažadant atlygị už seksualinị veiksmą, dažniausiai - finansinị atlygị. 86,3 proc. atvejų seksualinio nusikaltimo aukomis tapo moterys, 7,8 proc. atvejų seksualinė prievarta panaudota prieš vyriškos lyties asmenis, o 5,9 proc. atvejų įtarimai buvo pareikšti dèl seksualinès prievartos panaudojimo prieš abiejų lyčių asmenis. 62,7 proc. seksualinių nusikaltimų aukų sudarẻ mažamečiai asmenys (iki 14 metų amžiaus), iš jų 81,3 proc. sudare mergaitès ir 18,7 proc. - berniukai. Net 19,6 proc. nukentèjusiujų buvo jaunesni nei 10 metų amžiaus. 7,8 proc. atvejų aukomis tapo nepilnamečiai asmenys (14-18 m. amžiaus), o 29,5 proc. - suaugę pilnamečiai asmenys, visos jos - moterys. Nors didžiaja dalimi auka buvo giminystès ryšiais nesusijęs su tiriamuoju asmeniu ( 60,8 proc.), tačiau net 74,5 proc. atvejų tiek tiriamasis, tiek ir auka nurode buvę pažįstami ir ne kartą bendravę iki veikos. Nustatyta 39,2 proc. incesto atvejų, t. y. seksualinè prievarta buvo panaudota prieš artimą šeimos narị: 21,6 proc. - prieš vaiką, 9,8 proc. - prieš broli arba seserị, 2 proc. - prieš anūką. 5,9 proc. nukentejjusiomis tapo žmona arba sugyventinè. Tik 25,5 proc. atvejų tiriamieji nurodè aukos anksčiau nepažinoję. Didžioji dalis nukentejusiųjų seksualinès prievartos metu buvo blaivūs ( 60,8 proc.), tačiau 39,2 proc. nukentejusiujų buvo fiksuotas apsvaigimas nuo alkoholio, iš jų net 92 proc. alkoholị vartojo kartu su nusikaltimą įvykdžiusiu asmeniu. Jaunesnio amžiaus (1935 m.) asmenų, įtariamų ịvykdžius seksualinị nusikaltimą, aukomis didžiaja dalimi tapo mažamečiai 10-14 metų amžiaus asmenys (48 proc.) ir suaugę pilnamečiai asmenys (32 proc.). Vyresnių $36-55 \mathrm{~m}$. amžiaus tiriamujų aukomis 32 proc. tapo pilnamečiai asmenys, o 59 proc. atvejų - maža- 
mečiai, iš jų 38,5 proc. buvo jaunesni nei 10 metų amžiaus. Vyresnių nei 56 metų tiriamujjų asmenų aukomis tapo tik mažamečiai, t. y. jaunesni nei 14 metų asmenys, iš jų net 60 proc. buvo jaunesni nei 10 metų amžiaus.

73 proc. tiriamuju psichinès būsenos vertinime buvo konstatuotas emocinis nestabilumas, impulsų kontrolès sunkumai, žema tolerancija stresui ir frustracijai, vengimas prisiimti atsakomybę už savo veiksmus, dèl susiklosčiusios situacijos kaltino aplinką. Psichikos sutrikimų diagnostinių rodiklių analizè parode, kad 41 proc. tiriamujų iki nusikalstamos veikos padarymo buvo diagnozuoti ir kiti psichikos sutrikimai, dèl kurių jie buvo gydomi ambulatoriškai ar psichiatrijos stacionaruose, iš jų: 71 proc. tiriamujų diagnozuotas protinis atsilikimas, 19 proc. - šizofrenijos spektro sutrikimas, 10 proc. - afektiniai sutrikimai. Atlikus teismo psichiatrijos ekspertizę konstatuoti psichikos sutrikimai pasiskirste taip: dominavo asmenys su asmenybès sutrikimu (33 proc.), iš jų 35 proc. tiriamujų konstatuotas organinio tipo asmenybès sutrikimas, didžiąa dalimi sąlygotas ilgalaikio alkoholio vartojimo ir asmenybès degradacijos bei 29 proc. sudare emociškai nestabilaus tipo asmenybès sutrikimas. Lyginant nustatytas diagnozes iki ir po atliktos teismo psichiatrijos ekspertizès, nustatyta, kad ženkliai sumažèjo protinio atsilikimo diagnozių - jų liko tik 26 proc., iš jų 92 proc. nustatytas lengvas intelekto defektas. 1 tiriamajam konstatuotas vidutinis protinis atsilikimas, jị rekomenduota pripažinti nepakaltinamu. Taip pat sumažèjo šizofrenijos spektro sutrikimų - jų liko tik 6 proc., vieną šios grupès tiriamaji buvo rekomenduota pripažinti nepakaltinamu - jam konstatuota paranoidiné šizofrenija. Afektinių sutrikimų taip pat sumažejo (6 proc.), visi jie vertinti kaip išsivystę po nusikalstamos veikos padarymo. 1 tiriamajam konstatuotas psichikos sutrikimas dèl galvos smegenų pažeidimo dèl trauminès ir metabolinès kilmès (dèl ilgalaikio alkoholio vartojimo), vyraujant organinio psichosindromo klinikai su kognityvinių funkcijų pakenkimu, ji taip pat rekomenduota pripažinti nepakaltinamu. Visiems tiriamiesiems, kuriuos rekomenduota pripažinti nepakaltinamais, rekomenduotos priverčiamosios medicinos priemonès - psichiatrinis stebèjimas bendro stebejimo sąlygomis. Psichikos ir elgesio sutrikimai vartojant psichoaktyviąsias medžiagas, nesant komorbinio psichikos sutrikimo, buvo nustatyti 29 proc. tiriamujų, iš jų - tik 2 tiriamiesiems buvo konstatuotas narkotinių medžiagų vartojimas. 7,8 proc. tiriamųų konstatuota psichikos sutrikimo simuliacija.

\section{Išvados}

1. Asmuo, įvykdęs seksualinį nusikaltimą ir kuriam diagnozuotas psichikos ir elgesio sutrikimas vartojant psichoaktyviąsias medžiagas, charakterizuojamas kaip jauno, 19 - 35 m. amžiaus, augęs nepalankioje socialinèje aplinkoje, turintis vidurinị arba profesinị išsilavinimą, nedirbantis, vienišas.

2. Net 74,5 proc. atvejų tiriamasis ir auka buvo pažįstami ir ne kartą bendravę dar iki veikos, kas gali turèti ịtakos tam, jog daugiau nei pusè seksualinių nusikaltimų buvo padaryti tiriamojo gyvenamojoje vietoje.

3. 80 proc. tiriamujjų seksualinį nusikaltimą atliko būdami apsvaigę nuo alkoholio, 9,8 proc. tiriamujų nurodè nusikalstamos veikos aplinkybių nepamenantys dèl buvusio sunkaus apsvaigimo nuo alkoholio.

4. Nedidelè dalis tiriamujų kaltę dèl nusikalstamos veikos padarymo pripažino, iš jų tik 15,7 proc. nurodè tiesiogiai siekę patenkinti savo seksualinị potraukị.

5. Tiriamieji, kuriems diagnozuoti psichikos ir elgesio sutrikimai vartojant psichoaktyviąsias medžiagas, aukomis dažniau rinkosi paaugles mergaites arba jau suaugusias moteris bei mažamečius berniukus.

6. Tarp visų seksualinių nusikaltimų, i̇vykdytų tiriamujjų, kuriems diagnozuoti psichikos ir elgesio sutrikimai vartojant psichoaktyviąsias medžiagas, nustatyta net 39,2 proc. incesto atvejų.

7. Jaunesnio amžiaus tiriamieji aukomis dažniau rinkosi $10-16 \mathrm{~m}$. amžiaus arba pilnametes aukas, o vyresni nei 56 $\mathrm{m}$. amžiaus tiriamieji aukomis rinkosi tik itin jauno amžiaus, silpnesnes aukas.

8. Vertinant 73 proc. tiriamųjų psichinę būseną buvo konstatuotas emocinis nestabilumas, impulsų kontrolès sunkumai, žema tolerancija stresui ir frustracijai.

9. Tiriamiesiems, ịvykdžiusiems seksualinị nusikaltimą, kuriems diagnozuoti psichikos ir elgesio sutrikimai vartojant psichoaktyviąsias medžiagas, komorbidiškai dažniausiai nustatomas asmenybès sutrikimas bei intelekto funkciju deficito požymiai. Tik 3 asmenis rekomenduota pripažinti nepakaltinamais, visiems jiems konstatuotas sunkus psichikos sutrikimas, trikdantis gebejjimą suprasti savo veiksmų esmę ir juos valdyti.

\section{Literatūra}

1. Palermo GB. Recidivism in sexual offenders. International Journal of Offender Therapy and Comparative Criminology 2015;59(6):563-564.

https://doi.org/10.1177/0306624X15584984

2. Abbey A, Zawacki T, McAuslan P. Alcohol's effects on sexual perception. J. Stud. Alcohol 2000;61:688-697.

https://doi.org/10.15288/jsa.2000.61.688

3. Parkhill MR, Norris J, Gilmore AK, Hessler DM, George WH, Davis KC, Zawacki T. The effects of sexual victimization history, acute alcohol intoxication, and level of consensual sex on responses to sexual assault in a hypothetical scenario. Violence Vict 2016;31(5):938-956. 
https://doi.org/10.1891/0886-6708.VV-D-14-00042

4. Yoder J, Caserta DA. Associations between substance use in commission of sexual crimes and offense characteristics among youth: mitigating effects of substance use treatment. International Journal of Offender Therapy and Comparative Criminology 2016.

https://doi.org/10.1177/0306624X16651903

FORENSIC PSYCHIATRIC ASSESSMENT OF INDIVIDUALS WITH MENTAL AND BEHAVIOURAL DISORDERS DUE TO PSYCHOACTIVE SUBSTANCE USE, WHO COMMITED SEXUAL CRIMES

\section{A. Survilaitė}

Key words: sexual crimes, forensic psychiatry, forensic psychology, substance use.

Summary

Sexual violence is defined as any sexual act forced upon a person against his/her will or otherwise satisfaction of persons sexual desires with a minor. Our objective was to evaluate peculiarities of mental status, socio-demographic features, criminal behaviour characteristics and penal responsibility of sexual offenders with mental disorders due to substance use, who were referred to forensic psychiatric assessment in the National Service of Forensic Psychiatry in Lithuania, 2010 - 2016. Results revealed that alcohol was the most commonly used substance in sexual assaults and more than $80 \%$ of offenders were under alcohol influence at the moment of the crime. Mental status examination of sexual offenders reported impulsiveness, emotional lability and intellectual deficiency. Also dual diagnosis of substance dependency and personality disorders or mental retardation was common. Only 3 offenders were considered not responsible by reason of insanity due to severe mental illness, compulsory medical treatment was recommended to all of them.

Correspondence to: asurvilaite@gmail.com

Gauta 2017-09-25 